\title{
PENGARUH MOTIVASI KERJA TERHADAP KINERJA PEGAWAI PADA KANTOR KECAMATAN BANJAR BARU TULANG BAWANG
}

\author{
Lya Septiani Mutia ${ }^{(1)}$, Hazairin Habe ${ }^{(2)}$, Husna Purnama ${ }^{(3)}$ \\ Fakultas Ekonomi Universitas Sang Bumi Ruwa Jurai \\ lyaseptiani.mutia@gmail.com,hazairin.habe@fe.saburai.ac.id, husna.purnama@fe.saburai.ac.id
}

\begin{abstract}
Abstrak. Objek Penelitian adalah kantor Kecamatan Banjar Baru Tulang Bawang identifikasi masalah masih rendahnya pelayanan dan motivasi kerja yang berpengaruh terhadap kinerja. Rumusan masalah penelitian ini pengaruh motivasi terhadap peningkatan kinerja. Penelitian ini bertujuan untuk mengetahui pengaruh motivasi kerja terhadap kinerja pegawai pada kantor Kecamatan Banjar Baru Tulang Bawang selalu ditemui kendala dalam hal proses pencapaian kinerja pegawai. Hipotesis dalam penelitian ini adalah motivasi kerja berpengaruh terhadap kinerja pegawai pada kantor Kecamatan Banjar Baru Tulang Bawang. Penelitian ini merupakan penelitian kuantitatif menggunakan analisis regresi. Populasi dalam penelitian ini adalah seluruh pegawai yang berjumlah 30 pegawai. Terdapat pengaruh yang positif dan signifikan antara motivasi kerja terhadap kinerja pegawai dengan koefisienan korelasi (r) sebesar 0,630 dan koefisienan determinasi sebesar 0,397 . Hal ini berarti bahwa sebesar $39,7 \%$ kinerja pegawai yang ada dipengaruhi oleh motivasi kerja, sedangkan $60,3 \%$ lainnya ditentukan oleh variabel lain yang tidak dijelaskan dalam penelitian ini. Uji hipotesis dari persamaan regresi tersebut menunjukan bahwa motivasi kerja bernilai positif sebesar 0,535 atau nilai kinerja pegawai meningkat sebesar 1 poin.
\end{abstract}

Kata kunci: Kinerja, Motivasi, Pelayanan, Pengaruh.

\section{PENDAHULUAN}

Setiap organisasi dan
mempunyai bemberapa $\begin{array}{r}\text { lemapan } \\ \text { perkembangan yang berbeda sehingga } \\ \text { hanya organisasi dan lembaga yang tangguh } \\ \text { dan cepat tanggap terhadap perubahan- } \\ \text { perubahan lingkungan, teknologi dan ilmu } \\ \text { pengetahuan yang akan terus bertahan. }\end{array}$
Seperti halnya pemerintah kecamatan Banjar Baru Tulang Bawang sebagai salah satu lembaga non profit milik pemerintah yang terus maju, berkembang dan selalu tanggap terhadap perubahan jaman dengan meningkatkan penyelenggaraan tata pemerintah kecamatan yang baik melalui berbagai kebijakan, stratrgi dan aktivitas berkualitas bagi masyarakat.

Terlebih sejak diberlakukannya otonomi daerah, pelayanan publik menjadi ramai dipembincarakan, karena pelayanan publik merupakan salah satu variabel yang menjadi ukuran keberhasilan pelaksanan otonomi daerah. Apabila pelayanan publik yang dilakukan oleh pemerintah daerah baik/berkualitas, maka pelaksanaan otonomi daerah dapat dikatakan berhasil.

Untuk mencapai keberhasilan dalam pelayanan publik yang dilakukan oleh pemerintah daerah secara baik dan berkualitas, maka pelaksanan otonomi daerah dapat dikatakan berhasil apabila ditopang dengan adanya kemampuan dan motivasi kerja dari para pegawainya selaku abdi negara. Dengan motivasi kerja yang tinggi akan dapat memberi energi yang menggerakan segala potensi yang ada, menciptakan keinginan yang tinggi dan luhur, serta meningkatkan kebersamaan.

Untuk dapat melaksanakan tugas-tugas secara efektif maka seluruh tugas-tugas atau pekerjaan didalam suatu orgaisasi tersebut harus bekerja menurut aturan atau ukuran yang diciptakan dengan saling 
menghormati, saling membutuhkan, saling mengerti, dan menghargai hak dan kewajiban masing-masing dalam keseluruhan proses kerja operasional.

Pentingnya motivasi karena motivasi adalah hal yang menyebabkan, menyalurkan dan mendukung perilaku manusia, supaya mau bekerja giat dan antusias mencapai hasil yang optimal. Motivasi semakin penting karena pimpinan membagikan pekerjaan pada bawahanya untuk dikerjakan dengan baik dan terintegrasi kepada tujuan yang diinginkan.

Berdasarkan data, seseorang Camat masuk dalam katagori jabatan pada Golongan Jabatan IVB, kemudian seseorang Sekertaris kecamatan juga satu orang dengan golongan jabatan IIID, Kepala seksi sebnyak 5 orang dengan golongan masing-masing IIIA/B/D dan staf dengan golongan rata-rata golongan IIA/B/C/D. Pelaksanan pelayanan pembuatan KTP di kantor kecamatan baru bisa dilayani pada KTP senin -kamis mulai pukul 08.00 hingga 12.00 WIB. Sedangkan jumat mulai pukul $08.30-11.00 \mathrm{WIB}$.

Pelayanan kepada masyarakat pada kelembaggan pemerintah lainnya. Namun yang menjadi permasalahan sering aparatur tidak memberikan pelayanan sebagaimana standar pelayanan yang telah ditentukan dikarenakan motivasi kerja aparatur pada kelembaggan kecamatan memiliki pola kebiasaan terutama pada pola pelayanan yang lambat dan bahkan menyulitkan sehingga masyarakat sering mengeluh.

Sedangkan faktor lain seperti permasalahan Motivasi kerja sebagai salah satu gejala penurunan pelayanan tentu juga sangt berpengaruh pada kinerja, yang ternyata para aparatur kurang memberikan pelayanan kepada masyarakat dengan datang terlambat atau tidak masuk kerja yang pada akhirnya apresiasi masyarakat yang membutuhkan pelayanan sering timbul dan mengeluh tentang aparat memberikan pelayanan.
Selain itu juga dalam upaya memberikan pelayanan kepada masyarakat, peran aparatur kecamatan harus menunjukan pada pemberian pelayanan yang prima sehingga hal ini akan mengurai persepsi (pandangan) masyarakat selaku penerima pelayanan. Untuk hal ini yakni pemberian pelayanan kepada masyarakat, maka diperlukan suatu motivasi kerja yang menjadi pegangan sebagai peksanan beban kerja.

Berdasarkan pengamatan di lokasi penelitian dan kempampuan pegawai kecamatan Banjar Baru terkesan masih rendah dalam hal ini motivasi kerja yakni apa yang secara konsisten dipikirkan, sifat/ciri bawahaan dan relaksi-relaksi yang bersifat konsisten terhadap sistuasi atau informasi, konsep diri (self concept), sikap, nilai atau self image dari orang-orang, pengetahuan (knowledge), yaitu suatu informasi yang dimiliki seseorang khususnya pada bidang spesifik dan keterampilan (skill), kemampuan untuk mampu melaksanakan tugas-tugas fisik dan mental tertentu.

Selain itu juga motivasi kerja pegawai kurang memahami dan mengetahui suatu pendekatan penyelesian masalah dan tujuan yang berfokus pada perilaku bukan pada pribadi dan kurang mengetahui informasi yang menggunakan teknik pengutan dalam pekerjaan. Pelaksnan evaluasi dan laporan kegiatan kecamatan bidang pelayanan umum.

Selain itu juga kondisi tempat tinggal sebagaian besar pegawai yang jauh dari tempat kerja telah menjadi permasalahan sendiri terutama dalam memberikan pelayanan. Berdasarkan latar belakang tersebut peneliti tertarik untuk melakukan penelitian yang dengan judul: " Pengaruh Motivasi Kerja Terhadap Kinerja Pegawai Pada Kantor Kecamatan Banjar Baru Tulang Bawang”. 


\section{KAJIAN TEORI}

\section{Tinjauan Umum tentang Sumber Daya Manusia}

Dalam penulisan ini, penulis memiliki keyakinan bahwa untuk membicarakan motivasi, Kinerja atau lainya yang berhubungan dengan pekerjaan manusia karena didalamnya tidak terlepas dari peran manusia dan peran sumber daya manusia sangat menentukan. Oleh sebab itu sebelum merinci kerangka pikir yang berhubungan dengan judul, maka ada baiknya disajikan pengertian sumber daya manusia itu sendiri. Manajemen merupakan proses untuk mencapai tujuan organisasi manajemen bisa sebagai suatu kumpulan pengetahuan yang logis dan sistematis juga sebagai suatu kreativitas pribadi yang disertai suatu keterampilan.

Menurut Mary Parket Follet dalam bukunya menyatakan bahwa manajemen adalah seni mencapai sesuatu melalui orang lain (manajement is the art of getting things done thourh other). Dari definisi manajemen sebagaimana di atas, dapat diketahui bahwa ada dua istilah yang diberikan para ahli mengenai istilah manajemen yaitu sebagai seni yang merupakan kreativitas pribadi yang disertai suatu keterampilan dan ada pula yang memberikan definisi manajemen sebagai suatu ilmu yang merupakan kumpulan pengetahuan yang logis dan sistematis. Maka suatu organisasi untuk mencapai tujuannya tidak akan terlepas dari aktivitas manajemen.

Manajemen menginginkan tujuan organisasi tercapai dengan efisien dan efektif. Sedangkan pendapat Sadili Samsudin dalam buku Manajemen Sumber Daya Manusia (2006) yang menguntip pendapat G.R. Terry dalam Principless of Manajemen memberikan pengertian manajemen adalah suatu proses yang khas, yang terdiri dari tindakan perencanan, pengorganisasian, pengarahan dan penggerakan dan pengadilan yang dilakukan untuk menentukan serta mencapai sasaran yang telah ditentukan melalui pemanfaatan sumber daya manusia dan sumber-sumber daya lainya.

\section{Pengertian Motivasi}

Motivasi adalah serangkaian sikap dan nilai yang mempengaruhi individu untuk mencapai hal spesifik sesuai dengan tujuan individu. Sikap dan nilai tersebut merupakan suatu yang invisibel yang memberikan kekuatan untuk mendorong individu bertingkah laku dalam mencapai tujuan. Veitzhal (2005). Beliau juga mengemukakan hal yang dianggap sebagai dorongan individu yaitu arah prilaku (kerja untuk mencapai tujuan) dan kekuatan perilaku (seberapa kuat usaha individu dalam bekerja).

Selanjutnya Abraham Maslow (2012) berpendapat bahwa orang dewasa (pegawai bawahan) secara normal harus terpenuhi minimal $85 \%$ kebutuhan fisiologi, $70 \%$ kebutuhan rasa nyaman, 50\% kebutuhan sosial, 40\% kebutuan penghargaan, 5\% kebutuhan aktualisasi diri, keluarga, dan bisa menjadi penyebab terjadinya konflik kerja. Dengan demikian, jika kebutuhan pegawai tidak terpenuhi, pimpinan akan mengalami kesulitan dalam memotivasi pegawai.

Clark L. Hull (2012) berpendapat bahwa terjadi sebagai akibat dari reinforcement asumsinya menyatakan bahwa semua hadiah (reward) pada akhirnya didasarkan atas reduksi dan drive keseimbangan (home static drive). Teori Hull dirumuskan secara sistemaatik yang merupakan hubungan antara drive dan habit strength, yakni : kekuatan motivasi = fungsi (drive $\mathrm{x}$ habit) Habit strenght adalah hasil factor-factor reinforcement sebelumnya.

Motivasi menjadi masalah sangat penting dalam setiap usaha sekelompok 
orang yang berkerjasama dalam rangka pencapaian tujuan tertentu. Dalam usaha pencapain tujan-tujuan tertentu, motivasi tampak dalam dua segi yang berbeda, disatu pihak dari segi aktif atau dinamis maka motivasi tampak sebagai usha yang positif dalam menggerakan, mengarahkan dan mengarahkan daya dan potensi tenaga kerja agar secara produktif berhasil mencapai dan mewujudkan tujuan yang telah ditentukan sebelumnya. Sebaliknya kalau dilihat dari segi pasif atau statis, maka motivasi akan tampak sebagai kebutuhan dan juga sekaligus perangsang untuk dapat menggerakan potensi serta daya kerja manusia tersebut kearah yang diinginkan. ( Buchori Zainun, 2011).

Sedermayanti (2001) mendefinisikan bahwa motivasi adalah kondisi mental emosional yang mendorong aktifitas dan memeberi energi yang mengarah kepada pencapaian kebutuhan, memberi kepuasan atau mengurai ketidakseimbangan. Atau pendapatan lain tentang motivasi berikut dengan indikator, sebagaimana dikemukan oleh Maryanto, 2004, yang menyatakan bahwa: Indikator dari motivasi adalah kesungguhan dan keseriusan dalam melakukan pekerjaan, tanggung jawab terhadap diri sendiri, atasan dan sesama anggota, ketabahan akan kejujura dalam bekerja dan keuletan atau kekhawatiran jika mengalami kegagalan (Maryanto dkk, 2004).

\section{Kinerja Pegawai}

Dalam lembaga pemerintah, kinerja merupakan tuntutan kerja yang harus dipenuhi, sebab hanya dengan kinerja suatu lembaga pemerintah dapat diartikan telah memberikan pelayanan kepada masyarakat selaku abdi negara. Begitu juga dengan inspektorat dikabupaten sebagai lembaga pengawas yang bertanggung jawab langsung kepada wali kota, adalah lembaga yang bertanggung jawab langsung kepada wali kota, adalah sebuah lembaga yang bertanggung jawab didalam pengawasan penggunan anggaran.

Menurut Ambar Teguh Sulistiyaningsih (2003) “ kinerja merupakan kombinasi dari kemampuan, usha dan kesempatan yang dapat dinilai dari hasil kerjanya." Sedangkan menurut Anwar Prabu Mangkunegara (2009:67)," Kinerja adalah hasil kerja secara kualitas yang dicapai oleh seseorang karyawan dalam melaksanakan tugasnya sesuai dengan tanggung jawab yang diberikanya."

Begitu juga dengan pendapat Mink (2003) disadur dari Anwar Prabu Mangkunegara (2009) yang mengemukakan pendapatnya tentang kinerja menyatakan, bahwa induvidu yang memiliki kinerja yang tinggi memiliki beberapa karakteristik, yaitu diantaranya:

1. Berorientasi pada prestasi,

2. Memiliki kepercayan diri,

3. Berpengendalian diri,

4. Motivasi.

\section{METODE PENELITIAN}

\section{Objek Penelitian}

Sebagai objek penelitian ini adalah pegawai Kecamatan Banjar Baru Tulang Bawang yang beralamat di jalan Khuripan Jaya Makmur Banjar Baru. Penelitian ini dilaksanakan pada bulan Maret-Agustus 2019.

\section{Metode dan Teknik Pengumpulan Data}

Dalam penelitian ini jenis data yang diperlakukan adalah :

a. Data Primer

Data primer merupakan data dasar yang akan diperoleh langsung tanpa perantara orang atau lembaga lain sebagai pihak ketiga. Data primer ini diperoleh dengan wawancara melalui responden dengan menggunakan daftar pertanyaan. 
b. Data Sekunder

Data skunder merupakan data yang diperoleh melalui orang lain yang berhubungan dengan permasalahan yang dipecahkan. Data sekunder ini diperoleh melalui cara studi dokumenter yaitu mengumpulkan dan mempelajari brosurbrosur serta dokumen organisasi.

Adapun teknik yang digunakan dalam pengumpulan data adalah dengan :

1. Observasi, yaitu mengadakan survey atau pengamatan langsung kelokasi penelitian.

2. Interview atau wawancara, yaitu mengadakan tanya jawab langsung dengan pegawai.

3. Dokumentasi, yaitu mengumpulkan dan mencatat dokumentasi yang relevan.

4. Kuisioner, yaitu membuat pertanyaan yang berhubungan dengan varibael penelitian.

\section{Sampel dan Populasi}

Pada penelitian ini seluruh pegawai dijadikan responden. Berdasarkan data yang ada jumlah pegawai adalah 30 orang, kemudian menurut Suharsimi.Arikunto apabila objek penelitian kurang dari 100 maka lebih baik diambil semua. Menurut data yang ada jumlah populasi dalam penelitian ini berjumlah kurang 100 sehingga penulis mengambil semua populasi yaitu berjumlah 30 orang.

Menurut Nanang Martono (2011) mendefinisikan populais adalah seluruh objek atau subjek yang berada pada suatu wilayah dan memenuhui syarat-syarat tertentu berkaitan dengan masalah penelitian, atau keseluruhan unit atau induvidu dalam ruang ringkup yang akan diteliti. Adapun populasi dalam penelitian ini adalah seluruh pegawai kantor Kecamatan Banjar Baru Tulang Bawang yang berjumlah 30 orang.

\section{Metode Analisis Data}

Analisis kualitatif dilakukan dengan analisis tabel tanggal atau secara parsial yang akan menggambarkan kriteria masingmasing variabel yaitu kreteria variabel pengaruh Motivasi Pegawai dan Kinerja Pegawai.

Analisis kuantitatif untuk mengetahui hubunga Motivasi pegawai dan kinerja pegawai. Persamaan Regresi Linear Sederhana menentukan persamaan regresi linear sederhana untuk X :

$$
Y=a+b X+e
$$

Keterangan:

$$
\begin{aligned}
& \mathrm{Y}=\text { Kinerja pegawai } \\
& \mathrm{a}=\text { Konstanta } \\
& \mathrm{b}=\text { Koefisien regresi } \mathrm{X} \\
& \mathrm{X}=\text { Motivasi kerja } \\
& \mathrm{e}=\text { Faktor kesalahan }
\end{aligned}
$$

Untuk mengetahui besarnya pengaruh, penghitungan koefisien korelasi tersebut kemudian dilanjutkan dengan Rumus Koefisien Determinasi atau Koefisien Penentu (KP):

$$
K P=(r)^{2} x 100 \%
$$

Untuk menguji secara hipotesis secara parsial digunakan Uji t dengan rumus :

$$
t_{\text {hitung }}=\frac{r \sqrt{N-2}}{\sqrt{1-r^{2}}}
$$

Keterangan:

$$
\begin{array}{ll}
\mathrm{t}_{\text {hitung }} & =\text { Nilai } \mathrm{t} \\
\mathrm{r} & =\text { Koefisien Korelasi } \\
\mathrm{N} & =\text { Jumlah responden }
\end{array}
$$

Kriteria untuk Uji $\mathrm{t}$ adalah sebagai berikut :

a) Jika $t_{\text {hitung }}>t_{\text {tabel }}$ maka Ha diterima dan Ho ditolak. 
b) Jika $t_{\text {hitung }} \leq t_{\text {tabel }}$ maka Ha ditolak dan Ho diterima.

\section{HASIL DAN PEMBAHASAN}

\section{Analisis Kualitatif}

Hasil penelitian yang telah dilakukan di Kecamatan Banjar Baru Tulang Bawang mengenai motivasi kerja dengan jumlah 30 angket dan jumlah penyataan 8 butir dengan skor yang diberikan pada setiap butir pernyataan maksimal 5 dan minimal 1 yang diberikan kepada para pegawai, memperoleh skor minimum sebesar 27 dan skor maksimum sebesar 38, mean sebesar 34, median 33, modus 33 dan standar deviasi 3. Selanjutnya menentukan jumlah interval kelas $(K)$ dengan $n=30$ responden.

Hasil penelitian yang telah dilakukan di Kecamatan Banjar baru Tulang Bawang mengenai kinerja pegawai dengan jumlah 30 angket dan jumlah penyataan 4 butir dengan skor yang diberikan pada setiap butir pernyataan maksimal 5 dan minimal 1 yang diberikan kepada para pegawai, memperoleh skor minimum sebesar 12 dan skor maksimum sebesar 20, mean sebesar 16, median 16, modus 16 dan standar deviasi 2.

\section{Analisis Kuantitatif}

Hasil perhitungan persentase pencapaian dan kategori per indikator motivasi kerja terhadap 30 responden yang ada di kantor Kecamatan Banjar Baru Tulang Bawang yaitu daya dorong masuk ke dalam kategori sangat baik (84\%), hal tersebut diperkuat berdasarkan hasil pantauan peneliti pada saat menyebarkan dan mengambil angket pada kantor kecamatan Banjar Baru Tulang Bawang. Kemauan dan kerelaan masuk ke dalam kategori baik (78\%) dan (68,6\%) .membentuk keahlian, membentuk ketrampilan, tanggung jawab dan kewajiban masuk ke dalam kategori sangat baik (80\%), (93,3\%), (87,3\%) dan $(90,6 \%)$ dan tujuan termasuk kategori baik yaitu $(79,3 \%)$.

Hasil perhitungan persentase pencapaian dan kategori per indikator kinerja pegawai terhadap 30 Pegawai pada kantor Kecamatan Banjar Baru Tulang Bawang menunjukan bahwa rata-rata kinerja pegawai kantor Kecamatan Banjar Baru Tulang Bawang memiliki disiplin yang baik (73\%), dengan kecendrungan indikator yaitu pencapaian target berorientasi (85,3\%), Memeiliki Percaya diri masuk ke dalam kategori baik $(77,3 \%)$, berpengendalian diri masuk Kategori Baik (74\%) dan kompetensi masuk ke kategori baik $(78,6 \%)$.

Berdasarkan hasil analisis data yang telah dilakukan menunjukan bahwa terdapat pengaruh yang positif dan signifikan antara motivasi kerja terhadap kinerja pegawai pada kantor Kecamatan Banjar Baru Tulang Bawang. Pernyataan ini dibuktikan dengan hasil perhitungan uji t yang menghasilkan

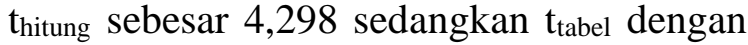
taraf signifikansi sebesar 5\% yaitu 2,045, maka $t_{\text {hitung }}>t_{\text {tabel }}$ dengan nilai 4,298 > 2,045, perbandingan tersebut mengartikan bahwa Ho ditolak dan Ha diterima yaitu terdapat pengaruh yang positif dan signifikan antara Motivasi Kerja Terhadap Kinerja Pegawai kantor Kecamatan Banjar Baru Tulang Bawang.

Hasil perhitungan uji $t$ tersebut diperkuat berdasarkan nilai koefisienan korelasi (r) sebesar 0,630 menunjukan bahwa terdapat keeratan antara variabel motivasi kerja dan kinerja pegawai .Kemudian untuk Nilai koefisien determinasi $\left(\mathrm{r}^{2}\right)$ sebesar 0,397 dan sumbangan efektif pengawasan sebesar $39,7 \%$. Sehingga harga tersebut menjelaskan bahwa terdapat pengaruh antara motivasi kerja terhadap kinerja pegawai pada kantor Kecamatan Banjar Baru Tulang Bawang, persentase 
pengaruhnya sebesar $39,7 \%$ dan $60,3 \%$ lainnya dipengaruhi oleh hal atau variabel lain yang tidak diteliti dalam penelitian ini.

Berdasarkan tabel 15 diperoleh nilai konstanta (a) $=2,206$ dan nilai koefisien arah regresi $=0,535$ maka persamaan garis regresinya adalah $\mathrm{Y}=\mathrm{a}+\mathrm{bX}$ maka, $\mathrm{Y}=$ $2,206+0,535 X$. Selanjutnya dari persamaan garis regresi tersebut menunjukan bahwa nilai koefisienan untuk pengawasan bernilai positif sebesar 0,535 yang berarti jika nilai pengawasan meningkat 1 poin, maka nilai disiplin kerja akan meningkat sebesar 0,535 poin.

Motivasi kerja akan berdampak langsung terhadap pegawainya, terutama dalam hal penyelesaian pekerjaan yang diberikan. Data hasil perhitungan persentase pencapaian dan kategori per indikator motivasi kerja dan kinerja pegawai terhadap 30 pegawai yang ada pada kantor Kecamatan Banjar Baru Tulang Bawang menunjukan bahwa rata-rata motivasi kerjanya sebesar $82,6 \%$ dan ratarata kinerja pegawai sebesar $73 \%$ masuk ke dalam kategori baik.

\section{KESIMPULAN DAN SARAN}

\section{Kesimpulan}

Berdasarkan hasil penelitian yang telah dilakukan dapat disimpulkan bahwa uji regresi linear sederhana diperoleh nilai konstanta $(\mathrm{a})=2,206$ dan nilai koefisien arah regresi $\mathrm{b}=0,535$ maka persamaan garis regresinya adalah $\mathrm{Y}=2,206+0,535 \mathrm{X}$ dari persamaan garis regresi tersebut menunjukan bahwa nilai koefisienan untuk motivasi kerja bernilai positif sebesar 0,535 yang berarti jika nilai motivasi kerja meningkat 1 poin, maka nilai kinerja pegawai akan meningkat sebesar 0,535 poin. Terdapat pengaruh yang positif dan signifikan antara motivasi kerja terhadap kinerja pegawai pada Kantor Kecamatan Banjar Baru Tulang Bawang Sebesar 39,7\% yang dipengaruhi oleh motivasi kerja yang ada.

\section{Saran}

Berdasarkan kesimpulan di atas terdapat saran mengenai motivasi kerja. Saran tersebut adalah perlunya perbaikan dan perhatian yang lebih pada indikator kerelaan, karena meskipun masuk ke dalam kategori baik tetapi memiliki persentase yang rendah dari pada indikator yang lainnya.

\section{DAFTAR PUSTAKA}

Arikunto, Suharsimi. 2013. Teknik Penelitian. Jakarta: Elangga.

Darwin, Charles. 2010. Teori Motivasi Insting. Bandung: Alfabeta.

Effendi, Sofian. 2007. Metode Analisis. Jakarta: Erlangga.

Furchan, Arief. 2009. Statistik Deskriptif. Surabaya: Erlangga.

Follet, Parket Marry. 2011. Manajemen Manusia. Jakarta: Erlangga.

Gestalt. 2009. Teori Motivasi. Bandung: Alfabeta.

Hadi, Sutrisno. 2008. Sumbangan Efektif. Yogyakarta: PT. Liberty.

L. Hull, Clark. 2012. Teori Motivasi. Bandung: Alfabeta.

Martono, Nanang. 2011. Teknik Populasi. Jakarta: Erlangga.

Mangkunegara, Anwar Prabu. 2009. Kinerja Karyawan Sukses. Yogyakarta: Penerbit Liberty. 
Maryanto dkk. 2004. Manajemen Sumber daya Manusia. Jakarta: Ghalia Indonesia.

Rivai. 2010. Motivasi kerja. Jakarta: Ghalia Indonesia.

Robins dalam Handoko. 2010. Motivasi Dalam Perkerjaan. Yogyakarta: Liberty Yogyakarta.

Sedermayanti. 2007. Manajemen Sumber Daya Manusia. Jakarta: Rajawali Pers.

Sudjana. 2009. Uji Linearitas. Jakarta: PT. Bumi Aksara.

Sulistyaningsih, Ambar Teguh. 2003. Kinerja Karyawan. Jakarta: Salemba Empat.

Sugiyono. 2010. Metode Penelitian Pendidikan: Pendekatan Kuantitatif, Kualitatif dan R\&D. Bandung: Alfabeta.

Umar, Husein. 2011. Desain Penelitian MSDM dan Perilaku Karyawan. Jakarta: Rajawali Pers.

Yamin, Sofyan. 2011. Regresi dan Korelasi dalam Genggaman Anda. Jakarta: Salemba Empat.

Zainun, Buchori. 2011. Motivasi. Jakarta: Salemba Empat. 